\title{
Isolation and expeditious morphological, biochemical and kinetic characterization of propolis-tolerant ruminal bacteria ${ }^{1}$
}

\section{Odimári Pricila Pires do Prado², Lucia Maria Zeoula², Lucimar Pontara Peres de Moura², Selma Lucy Franco ${ }^{2}$, Sara Barbosa de Paiva ${ }^{3}$, Pedro Braga Arcuri ${ }^{3}$}

\footnotetext{
1 Projeto financiado pelo CNPq.

2 UEM - Universidade Estadual de Maringá - Maringá, PR, Brasil.

${ }^{3}$ Embrapa Gado de Leite - Juiz de Fora, MG, Brasil.
}

ABSTRACT - It was aimed in this work to evaluate bacterial strains tolerant to products based on propolis (LLOS) through the isolation, morphological and biochemical characterization techniques in diets with roughage:concentrate ratio 100:0 and 50:50. For roughage diets, the products LLOSC1 and LLOSB3 were evaluated, and for 50:50\% diets, the products LLOSC1, LLOSD1, LLOSA2, and LLOSC3, which differed in alcoholic concentrations (1, 2 and 3) and propolis (A, B, C and D) concentrations. The ruminal liquid was anaerobically incubated at $39^{\circ} \mathrm{C}$ for 6 days in medium containing LLOS. After isolation, the strains were submitted to Gram staining and the bacterial growth was monitored by photospectrometer. It was evaluated the strain growth in the presence of the following subtracts: arabinose, cellulose, glucose, cellobiose, xylose, fructose, and lactose. In roughage diets, strains tolerant to LLOSC1 and LLOSB3 were similar to carbohydrates degradation, except lactose in which LLOSC1 was superior to strains tolerant to LLOSB3. For diets with 50:50 roughage:concentrate ratio, the products LLOSC3 and LLOSA2 stood out because they selected the highest number of strains able to degrade most of the tested carbohydrates. The results suggest that tolerance to propolis is higher in Gram-positive strains with several growth metabolic levels.

Key Words: additives, bacterial strains, carbohydrates, rumen fermentation

\section{Isolamento e caracterização expedita morfológica, bioquímica e cinética de bactérias ruminais tolerantes a própolis}

RESUMO - Objetivou-se avaliar cepas bacterianas tolerantes a produtos à base de própolis pelas técnicas de isolamento, caracterização morfológica e bioquímica, em dietas com relação volumoso: concentrado de 100:0 e 50:50. Para dietas volumosas foram avaliados os produtos LLOSC1 e LLOSB3 e, para dietas 50:50\% os produtos LLOSC1, LLOSD1, LLOSA2 e LLOSC3, diferentes quanto aos teores alcoólicos (1, 2 e 3) e as concentrações de própolis (A, B, C e D). O líquido ruminal foi incubado anaerobiamente a $39^{\circ} \mathrm{C}$ durante 6 dias em meio contendo LLOS. Após o isolamento, as cepas foram submetidas à coloração de Gram e o crescimento bacteriano foi monitorado por espectrofotômetro. Foi avaliado o crescimento das cepas na presença dos substratos: arabinose, celulose, glicose, celobiose, xilose, frutose e lactose. Em dietas volumosas as cepas tolerantes a LLOSC1 e LLOSB3 foram semelhantes na degradação dos carboidratos, exceto lactose no qual LLOSC1 foi superior às cepas tolerantes a LLOSB3. Para dieta 50:50 de volumoso:concentrado, destacaram-se os produtos LLOSC3 e LLOSA2, que selecionaram maior número de cepas capazes de degradar a maioria dos carboidratos testados. Os resultados sugerem que a tolerância à própolis foi maior nas cepas Gram-positivas, com níveis metabólicos de crescimento diversos.

Palavras-chave: aditivo, carboidratos, cepas bacterianas, fermentação ruminal

\section{Introduction}

Bacteria present in the rumen are in charge of the fermentation processes that supply the host mainly with volatile fatty acids (VFA) and microbial protein. Among these bacteria, cellulolytc, hemicellulolytic and pectinolytics and soluble sugar fermenters are the majority (Russell, 2002). Overall, cellulolytic bacteria - acetate producer and methanogenic - are Gram-positive, and the producers of propionate are Gram-negative. In addition, there are the Gram variable, changing its membrane structure according to the medium in which they are inserted (Robson \& Stewart, 1997).

The antibacterial action of the propolis was verified by Antunes et al. (1996) in assays on antibiosis with propolis for $10 \mathrm{Gram}$-positive bacteria and $20 \mathrm{Gram}$-negative aerobic 
ones; it was observed that the antibacterial activity of the propolis was more effective upon the Gram-positive bacteria. The mechanism of antimicrobial activity of the propolis is complex and according to Takaisi-Kikuni \& Schilcher (1994), it is probably involved in the bacterial RNA-polymerase inhibition.

The use of propolis as an additive for the ruminant diets has being studied and in one of those studies, Broudiscou et al. (2000) tested the effect of propolis upon the fermentation and methanogenesis and observed that it has increased the production of propionate in $10.3 \%$. Stradiotti Jr. et al. (2004) observed that the addition of propolis extract to an incubation of ruminal liquid with $100 \mathrm{mg}$ of brachiaria hay improved the digestion rate, when compared to the control. Twelve products based on powder propolis extract, denominated as LLOS, were evaluated on in vitro dry matter digestibility by Prado (2005) and the products that resulted in positive effects, better than control and monensin, when added to roughage based diets were LLOSB3 and LLOSC1; and to 50:50 of roughage:concentrate diets, were LLOSC1, LLOSD1, LLOSA2 and LLOSC3. Thus, the aim of this study was to isolate and to characterize bacteria strains tolerant to these products based on propolis (LLOS) in the two following situations: roughage based diets and the 50:50 ratio roughage:concentrate ratio.

\section{Material and Methods}

The experiment was carried in Campo Experimental de Coronel Pacheco (the experimental field), Minas Gerais State, Brazil (CECP), at the Laboratório de Microbiologia do Rúmen (Ruminal Microbiology Laboratory) located at the headquarters of Embrapa Gado de Leite of Juiz de Fora, Minas Gerais State and at the Laboratório de Farmacotécnica (Pharmacotechnique Laboratory) of the Universidade Estadual de Maringá (State University of Maringá), Maringá, Paraná State, Brazil.

The products based on propolis extract (LLOS), powder, were denominated LLOS (product registered in Instituto Nacional de Propriedade Industrial - Brazil, $n^{\circ}$ 0605768-3) and they differed in three alcoholic extractions (attributed the numbers 1, 2 and 3 from the lowest to the highest level of alcohol) and in four concentrations of propolis (A, B, C and $\mathrm{D}$, from the lowest to the highest concentration), which were prepared according to the methodology developed by Franco \& Bueno (1999). The evaluated products were LLOSC1, LLOSB3 in diets with $100 \%$ of roughage (corn silage) and the products LLOSC1, LLOSD1, LLOSA2, and LLOSC3 in diets with $50: 50 \%$ of roughage:concentrate (Prado, 2005).
However, for the present experiment, a re-extraction of the LLOS products was needed, since they were presented in the solid form, what hindered their inclusion in the culture medium. Accordingly, it was weighted $5 \mathrm{~g}$ of the product in a sterilized container and approximately $75 \mathrm{~mL}$ of alcohol was added $(50: 50 \mathrm{~V} / \mathrm{V})$. The solution was taken to ultrasonic bath for 15 minutes. Then, this solution was filtered in sintered glass filter, and the solid residual was washed twice, resulting in a solution of $100 \mathrm{~mL}$ of product. The sterilizing filtration procedure was carried out in laminar flow cabinet previously disinfected, using $0.22 \mu \mathrm{m}$ wide Millipore, in the presence of constant flow of $\mathrm{CO}_{2}$.

The anaerobic culture medium for the ruminal bacterial isolation procedure was previously prepared. The bacterial culture medium called GSM (Growth Study Medium; Odenyo et al. 1998) contained the following ingredients in $100 \mathrm{~mL}$ : $0.3 \mathrm{~g}$ glucose; $0.2 \mathrm{~g}$ tryptone; $0.1 \mathrm{~g}$ meat extract; $5 \mathrm{~mL}$ mineral solution 1 (mineral solution $1=0.6 \mathrm{~g} \mathrm{~K}_{2} \mathrm{HPO}_{4}$ in $100 \mathrm{~mL}$ distilled water in anaerobic medium); $5 \mathrm{~mL}$ mineral solution 2 (mineral solution $2=0.6 \mathrm{~g} \mathrm{KH}_{2} \mathrm{PO}_{4} ; 1.2 \mathrm{~g} \mathrm{NH}_{4} \mathrm{SO}_{4} ; 1.2 \mathrm{~g}$ $\mathrm{NaCl} ; 0.25 \mathrm{~g} \mathrm{MgCl} 7 \mathrm{H}_{2} \mathrm{O}$ and $0.16 \mathrm{~g} \mathrm{CaCl}_{2} 2 \mathrm{H}_{2} \mathrm{O}$ in $100 \mathrm{~mL}$ of distilled water in anaerobic medium, according to Bryant \& Burkey, 1953); $1 \mathrm{~mL}$ solution volatile fatty acids $(3.85 \mathrm{~mL}$ glacial acetic acid; $3.0 \mathrm{~mL}$ propionic acid; $1.84 \mathrm{~mL}$ butyric acid; $0.47 \mathrm{~mL}$ isobutyric acid; $0.55 \mathrm{~mL}$ 2-methylbutyric acid; $0.55 \mathrm{~mL}$ valeric acid; $0.55 \mathrm{~mL}$ isovaleric acid; $700 \mathrm{~mL} \mathrm{NaOH}$ at $0.2 \mathrm{M}$ and sufficient amount of distilled water for $1000 \mathrm{~mL}$ ); $0.1 \mathrm{~mL}$ resazurin; $0.4 \mathrm{~g}$ of $\mathrm{Na}_{2} \mathrm{CO}_{3}$; and $81.9 \mathrm{~mL}$ of distilled water.

Furthermore, it was added to the GSM complex B vitamins, whose composition contained $20 \mathrm{mg}$ pyrodoxamin $2 \mathrm{HCl} ; 20 \mathrm{mg}$ riboflavin; $20 \mathrm{mg}$ tyamin; $20 \mathrm{mg} \mathrm{Ca} \mathrm{D}$-panthenate; $10 \mathrm{mg}$ lipoic acid; $1 \mathrm{mg}$ P-aminobenzoic acid; $0.5 \mathrm{mg}$ folic acid; $0.5 \mathrm{mg}$ cyancobalamin; $0.4 \mathrm{mg}$ vitamin $\mathrm{K} ; 10 \mathrm{mg}$ pyridoxal $\mathrm{HCl} ; 0.5 \mathrm{mg}$ biotin; $20 \mathrm{mg}$ nicotinamide; $10 \mathrm{mg}$ pyridoxine in $100 \mathrm{~mL}$ of distilled water.

Where it was necessary, it was used an anaerobic dilution solution (ADS) composed of: $3.75 \mathrm{~mL}$ mineral solution $1 ; 3.75 \mathrm{~mL}$ mineral solution 2 and sufficient amount of distilled water for $100 \mathrm{~mL}$. For the isolation, it was used solid medium, roll-tube (Hungate, 1969), with similar composition to GSM, that is, the following ingredients for $100 \mathrm{~mL}$ medium: $2.0 \mathrm{~mL}$ agar; $0.1 \mathrm{~g}$ glucose; $0.4 \mathrm{~g}$ cellobiose; $0.1 \mathrm{~g}$ meat extract; $0.2 \mathrm{~g}$ tryptone; $0.05 \mathrm{~g}$ soluble starch; $5 \mathrm{~mL}$ mineral solution $1 ; 5 \mathrm{~mL}$ mineral solution $2 ; 0.1 \mathrm{~mL}$ resazurin; $1.0 \mathrm{~mL}$ volatile fatty acids; $30.0 \mathrm{~mL}$ clarified ruminal liquid; $0.2 \mathrm{~mL}$ hemim; $0.4 \mathrm{~g} \mathrm{Na}_{2} \mathrm{CO}_{3}$ and $52.9 \mathrm{~mL}$ of distilled water.

For obtaining samples of the ruminal content, four cannulated Holstein-Zebu cows in the rumen and fed on diets containing 50:50 and 100:0 of roughage:concentrate 
were used. The cows were kept in a covered stall with access to fresh water and trough equipped with Calan Gate - electronic gate - that allowed each cow to follow just one determined diet. The individual intake was recorded daily. For each treatment, two cows have received the 50:50\% roughage:concentrate diet ( $56.5 \%$ dry matter; $13.8 \%$ crude protein; $35.2 \%$ neutral detergent fiber; $20.5 \%$ acid detergent fiber; $2.9 \%$ ether extract and $42.3 \%$ of nonstructural carbohydrate), and two cows have received $100 \%$ of corn silage $(26.0 \%$ dry matter, $7.1 \%$ crude protein, $58.4 \%$ neutral detergent fibre, $35.4 \%$ acid detergent fibre, $3.1 \%$ ether extract and $25.1 \%$ nonstructural carbohydrate). The adaptation period to the experimental diets was 15 days. To the concentrate, it was added $1 \%$ mineral mixture (composition per kilogram of mineral salt: $65.0 \mathrm{~g}$ phosphorus; $130.0 \mathrm{~g}$ calcium; $5.0 \mathrm{~g}$ magnesium; $13.0 \mathrm{~g}$ sulphur; $700 \mathrm{mg}$ ion, $850 \mathrm{mg}$ copper; $1.000 \mathrm{mg}$ manganese, $120 \mathrm{mg}$ iodine, and $80 \mathrm{mg}$ cobalt). After this period, manual collection of the ruminal content carried out during the morning, just before the morning feeding, was accomplished.

The diets were alternated, that is, the animals fed $100 \%$ of corn silage started to be fed on $50: 50 \%$ of corn silage:concentrate and vice-versa. This procedure aimed to reduce interference among specific microbiota of animals.

The sampling of the ruminal content - approximately $1.0 \mathrm{~L}$-was accomplished before the feeding to obtain a more uniform microbial population, with little food particles, therefore, avoiding any filtering procedure, which would take a considerable time and could alter the ruminal microbiota just by exposing them to oxygen in the air. The ruminal content was filtered only once and it was immediately put in a thermos bottle (previously heated at $39^{\circ} \mathrm{C}$ ). Afterwards, the sampled material was taken immediately to the Ruminal Microbiology Laboratory.

From each sample of the ruminal content, it was taken $5 \mathrm{~mL}$, which was injected using sterilized needles and syringes into sterilized $100-\mathrm{mL}$ flasks, containing $75 \mathrm{~mL}$ of anaerobic culture medium (GSM), $2.0 \mathrm{~mL}$ cysteine $\mathrm{HCl}$ (1.25\%), $1.0 \mathrm{~mL}$ Vitamin B complex, as previously described, and $3.0 \mathrm{~mL}$ of solution containing LLOS to be tested.

The inoculated flasks were incubated at $39^{\circ} \mathrm{C}$ for six days. After the incubation, $1.0 \mathrm{~mL}$ of the suspension was transferred to Hungate test tubes (anaerobic test tube, 18 $\times 150 \mathrm{~mm}$; Bellco ${ }^{\circledR}$ ) containing: $8 \mathrm{~mL}$ of GSM, $0.1 \mathrm{~mL}$ of vitamin $\mathrm{B}$ complex, $0.2 \mathrm{~mL}$ of cysteine $\mathrm{HCl}$ and $0.3 \mathrm{~mL}$ of the testing LLOS.

After two days of cultivation, $1.0 \mathrm{~mL}$ of the suspension was taken from each tube and diluted in anaerobic solution
(ADS) until reaching the following dilutions: $10^{-5}, 10^{-6}$, and $10^{-7}$. Isolation was performed according to Hungate, (1969, "roll-tubes"). After preparing the dilutions, $0.3 \mathrm{~mL}$ was anaerobically transferred to tubes containing GSM with melted agar. Thus, the inoculum was mixed to the culture medium, and then, the tube was rolled in cooled water, forming a film of agar along its length. The tubes were, then, incubated at $39^{\circ} \mathrm{C}$.

Two days after the inoculation in the roll-tubes, the isolated bacterial colonies were chopped under anaerobiosis in new tubes containing: $8 \mathrm{~mL}$ of GSM with addition of $0.1 \mathrm{~mL}$ of vitamin $\mathrm{B}$ complex and $0.2 \mathrm{~mL}$ of cysteine $\mathrm{HCl}$.

Confirmation of purity of the strains was done by morphological observation - using an optical microscope in objective lens 100 with immersion oil - in natura culture as well as in culture stained using the Gram technique.

The isolated stains that demonstrated the ability to tolerate the LLOS tested were classified according to the phenotypical (morphology, Gram-staining), kinetics (growth curve), and physiological characteristics (growth in different substrate). For this last evaluation, it was used the same medium-GSM-however, considerably replacing the glucose for one of the following sugars: arabinose, cellulose, cellobiose, xylose, fructose and lactose. On the other hand, the growth curves were established through the cultivation of the isolated strains in liquid medium containing only glucose as source of carbohydrate. It was used the length of $600 \mathrm{~nm}$ in spectrophotometer adapted for the readings of test tubes. The Gram staining was carried out in samples of strains in exponential growth phase, which were periodically photographed.

Statistical analyses was done using WinBUGS PACKAGE (Lunn, 2000), in which Bayesian analysis of data were made. It was used Gibbs samples and chains of Markov with 20.000 and 30.000 iterations and the burning and interval thin used was determinate from the analysis of generated chains. The credibility interval was estimated to $95 \%$ level.

The differences among LLOS products were compared after the generation of GIBBS samples. Comparisons in the credibility interval of the differences that did not contain the value zero were considered statistically different.

Convergence of chains was monitored from tests for the diagnosis of Heidelberg and Welch described by Cowles et al. (1995), available in the library CODA (Convergence Diagnosis and Output Analysis), implemented in the program $\mathrm{R}$ version 2.9.1. $\mathrm{R}$ (2009) and convergence to all generated chains were checked. 


\section{Results and Discussion}

Sixty-six bacterial strains tolerant to the product based on propolis (LLOS) were isolated in inoculums from cows fed $50 \%$ of corn silage and $50 \%$ concentrate. However, it was obtained 49 bacterial strains from cows fed $100 \%$ of corn silage, totalizing the isolation of 115 bacterial strains (Table 1). The isolation of bacteria without the propolis pressure, that is, controlled by the experimental protocol was not possible due to the non-separation of the colonies.

Overall, for the content of flavonoids in the LLOS products (measured as the equivalent of chrysin, Prado, 2005) which ranged from 0.031 to $0.001 \mathrm{mg} / \mathrm{g}$ of the product, it was observed that the higher concentration of flavonoids, regardless of the roughage:concentrate ratio of the diets, the largest was the percentage (without credibility interval overlapping) of LLOS tolerant organisms in relation to the attempts of colonial isolation (52.6 vs $13.8 \%$ of tolerant strains).
For the product LLOSC1 $(0.018 \mathrm{mg}$ of flavonoid/g of LLOS) tested in two conditions of feeding, the percentage of the product-tolerant strains was $36.5 \%$ for the diet with $100 \%$ roughage and $29.8 \%$ to $50: 50 \%$ roughage:concentrate. Despite of the numerical difference between isolated LLOSC1 in the tested two diets, they were statistically similar (credibility interval overlapping).

For different proportions of roughage:concentrate, it was the highest percentage of Gram-positive bacterial strains (80.9\%) in relation to the Gram-negative ones (19.1\%), which were tolerant to LLOS (Table 2). It was observed the morphologic predominance of LLOS-tolerant bacterial strains, in which rods, curved rods, coccobacillus, diplococcus, streptococcus, staphylococcus were majority.

According to Russell (2002), the majority of the Grampositive bacteria are more susceptible to actions of antibiotics and ionophores than the Gram-negative bacteria. However,most of the observed strains were Gram-positives, regardless of diets, which may indicate that the mechanisms

Table 1 - Percentage of the pure strains bacteria tolerant to product based on propolis LLOS ${ }^{1}$ in relation to the attempts of colonial isolation obtained from cows

\begin{tabular}{|c|c|c|c|c|c|c|}
\hline \multirow[t]{2}{*}{ LLOS products ${ }^{1}$} & \multirow{2}{*}{$\begin{array}{l}\text { Total flavonoids } \\
(\mathrm{mg} / \mathrm{g} \text { of LLOS })^{2}\end{array}$} & \multirow{2}{*}{$\begin{array}{l}\text { Attempts of } \\
\text { colonial isolation }\end{array}$} & \multirow{2}{*}{$\begin{array}{l}\text { Strains } \\
\text { (absolute numbers) }\end{array}$} & \multirow{2}{*}{$\begin{array}{l}\% \text { of strains in } \\
\text { relation to the } \\
\text { attempts estimated }\end{array}$} & \multicolumn{2}{|c|}{ Credibility interval } \\
\hline & & & & & $2.5 \%$ & $97.5 \%$ \\
\hline & \multicolumn{6}{|c|}{$100 \%$ corn silage } \\
\hline LLOSC 1 & 0.018 & 72 & 26 & 36.5 & 25.9 & 47.6 \\
\hline LLOSB3 & 0.011 & 84 & 23 & 27.9 & 18.9 & 27.8 \\
\hline \multicolumn{7}{|c|}{$50 \%$ corn silage and $50 \%$ concentrate } \\
\hline LLOSD 1 & 0.031 & 36 & 19 & $52.6 \mathrm{a}$ & 36.9 & 67.9 \\
\hline LLOSC3 & 0.030 & 34 & 17 & $50.0 \mathrm{a}$ & 33.8 & 65.9 \\
\hline LLOSC 1 & 0.018 & 75 & 22 & $29.8 b$ & 20.3 & 40.3 \\
\hline LLOSA2 & 0.001 & 63 & 8 & $13.8 \mathrm{c}$ & 6.7 & 23.0 \\
\hline Total & & 364 & 115 & 31.6 & & \\
\hline
\end{tabular}

${ }^{1}$ LLOS: product based on extract of propolis with extraction under different alcoholic levels (1, 2 and 3 ) and different concentrations of propolis (A, B, C, and D), LLOSC1, LLOSB3, LLOSD1, LLOSC3, and LLOSA2.

2 Concentration of total flavonoids measured in concentration of chrysin through the chemical analysis of chromatography (High Performance Liquid Chromatography) (Prado, 2005). Means in same column with different letters differ statistically.

Table 2 - Percentage of Staining Gram of pure strains bacteria tolerant product based on propolis LLOS $^{1}$, incubated in different proportions of roughage:concentrate

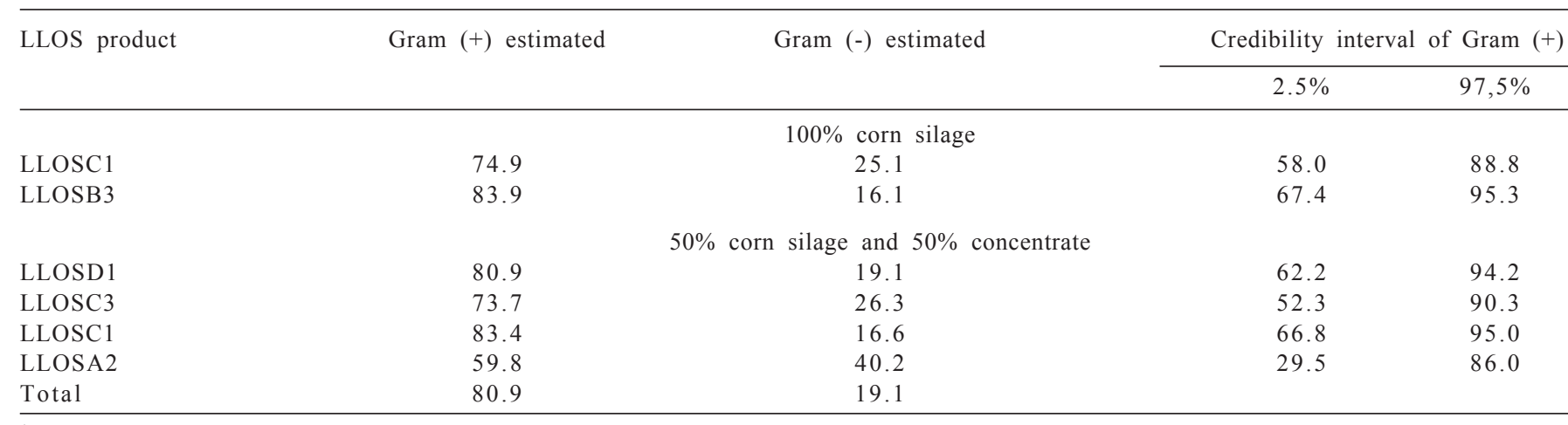

${ }^{1}$ LLOS: product based on extract of propolis with extraction under different alcoholic levels (1, 2 and 3 ) and different concentration of propolis (A, B, C and D), LLOSC1, LLOSB3, LLOSD1, LLOSC3, and LLOSA2. 
of action of the propolis can be different from the action of the ionophores. This fact was already observed by TakaisiKikuni \& Schilcher (1994) who suggested that the mechanism of antimicrobial action of the propolis is based on the RNA-polymerase inhibition, with a possibility that such mechanism is the result of a synergistic effect between flavonoids, hydroxy acids and sesquiterpenes.

During the six-day incubation period used in the isolation methodology, it may have occurred some adverse situations, as for example a reduction of substrate that consequently might have favored the Gram-positive bacterial strain that are able to sporulate, unlike Gram-negative bacteria (Foster, 1956).

In diets with $100 \%$ corn silage, LLOSC 1 and LLOSB3 tolerant strains were similar (credibility interval coincide) in the ability to ferment cellulose, celubiose, arabinose, xylose and fructose (Table 3). But strains tolerant to the product based on propolis LLOSC1 were more able (no overlapping of credibility) to ferment lactose (96.4\%) than the LLOSB3 tolerant strains $(80.0 \%)$.

Table 3 - Fermentation ab aaility under different carbohydrate expressed in percentage of ruminal bacteria strains tolerant to product based on propolis $\operatorname{LLOS}^{1}$

\begin{tabular}{|c|c|c|c|c|}
\hline \multirow[t]{2}{*}{ LLOS product } & \multirow[t]{2}{*}{ Roughage: concentrate } & \multirow[t]{2}{*}{ Effective $(+)$ estimated } & \multicolumn{2}{|c|}{ Effective $(+)$ credibility interval } \\
\hline & & & $2.5 \%$ & $97,5 \%$ \\
\hline \multicolumn{5}{|c|}{ Cellulose } \\
\hline LLOSB3 & $100: 0$ & 36.1 & 18.6 & 55.6 \\
\hline LLOSD 1 & $50: 50$ & $52.3 \mathrm{ab}$ & 31.3 & 72.4 \\
\hline LLOSC3 & $50: 50$ & $63.1 \mathrm{a}$ & 41.1 & 82.5 \\
\hline \multicolumn{5}{|c|}{ Cellobiose } \\
\hline LLOSC 1 & $100: 0$ & 89.4 & 75.9 & 97.7 \\
\hline LLOSB3 & $100: 0$ & 75.9 & 57.8 & 90.1 \\
\hline LLOSD1 & $50: 50$ & $52.4 \mathrm{~b}$ & 31.8 & 72.8 \\
\hline LLOSC3 & $50: 50$ & $89.5 \mathrm{a}$ & 72.6 & 98.6 \\
\hline LLOSC1 & $50: 50$ & $74.9 \mathrm{ab}$ & 56.1 & 89.7 \\
\hline LLOSB3 & $100: 0$ & 48.1 & 29.4 & 67.2 \\
\hline LLOSD 1 & $50: 50$ & 61.7 & 40.6 & 80.9 \\
\hline LLOSC3 & $50: 50$ & 73.6 & 52.2 & 90.1 \\
\hline LLOSC 1 & $50: 50$ & 45.9 & 26.9 & 65.5 \\
\hline \multirow[t]{2}{*}{ LLOSA2 } & $50: 50$ & 70.1 & 40.1 & 92.5 \\
\hline & \multicolumn{4}{|c|}{ Xylose } \\
\hline LLOSC1 & $100: 0$ & 64.2 & 46.1 & 80.4 \\
\hline LLOSB3 & $100: 0$ & 48.0 & 29.4 & 67.2 \\
\hline LLOSD1 & $50: 50$ & 57.0 & 35.80 & 76.8 \\
\hline LLOSC3 & $50: 50$ & 68.3 & 46.3 & 86.7 \\
\hline LLOSC1 & $50: 50$ & 62.4 & 42.4 & 80.2 \\
\hline LLOSA2 & $50: 50$ & 60.1 & 29.6 & 86.2 \\
\hline LLOSA2 & \multicolumn{4}{|c|}{ Lactose } \\
\hline LLOSC1 & $100: 0$ & $96.4 \mathrm{Aa}$ & 87.1 & 99.9 \\
\hline LLOSB3 & $100: 0$ & $80.0 \mathrm{~b}$ & 62.6 & 92.8 \\
\hline LLOSD1 & $50: 50$ & $90.5 \mathrm{ab}$ & 75.0 & 98.7 \\
\hline LLOSC3 & $50: 50$ & $94.7 \mathrm{a}$ & 81.5 & 99.8 \\
\hline LLOSC1 & $50: 50$ & $75.0 \mathrm{Bb}$ & 56.5 & 89.8 \\
\hline LLOSA2 & $50: 50$ & $80.0 \mathrm{ab}$ & 51.9 & 97.2 \\
\hline
\end{tabular}

$(+)$ : visual growth in $48 \mathrm{hs}$; (-): no sings of growth until 48 hours of incubation; ${ }^{1}$ LLOS: product based on propolis extract under different alcoholic levels (1, 2 , and 3$)$ and different concentrations of propolis (A, B, C, and D), LLOSC1, LLOSB3, LLOSD1, LLOSC3, and LLOSA2. Means in the column with different lowercase letters in the same diet differ statistically. Different uppercase letters in the column refer to contrast by LLOSC1 50:50 diet and LLOSC1 100:0 diet and differs statistically. 
The product based on propolis LLOSB3 tolerant strains were more specific, e.g, from the 23 isolated strains (Table 2), only six strains were able to degrade all carbohydrates, suggesting the isolation of the bacterial that present niches of specific degradation. These data suggest that LLOSB3 has in its composition active compounds, extracted during its preparation, which is different from LLOSC1, therefore selecting different bacteria predominant in diets based on $100 \%$ of corn silage.

Among the four LLOS products tested in diets containing 50:50\% of corn silage: concentrate (Table 3 ), it was observed that the highest cellulose fermentation ability (no overlapping of credibility interval) was presented by the LLOSA2, LLOSC 3 and LLOSD1 tolerant strains $(70.0 \%$, $63.1 \%$ and $52.3 \%$, respectively) and the lowest value was for LLOSC1 tolerant strains (33.4\%) but it was not different from LLOSD1 tolerant strains. However, the highest cellobiose fermentation ability (no overlapping of credibility interval) was presented by the LLOSC 3 tolerant.

However, the highest cellobiose fermentation ability (no overlapping of credibility interval) was presented by the LLOSC 3 tolerant strains on LLOSD1 tolerant strains (89.5 vs 52.4\%), not differing from LLOSA2 (79.8\%), LLOSC1 (74.9\%) tolerant strains.

The lowest fructose fermentation ability ( no overlapping of credibility interval) was present by the LLOSD 1 tolerant strains $(57.3 \%)$ and the highest values were for LLOSC3, LLOSC 1 and LLOSA2 tolerant strains, which did not differ (overlapping of credibility).

The highest ability to lactose fermentation was presented by was presented by LLOSC 3 tolerant strains ( $94.7 \%$ and credibility interval does not coincide) and the lowest ability was presented by LLOSC1 tolerant strains $(75.0 \%)$ in $50: 50 \%$ roughage:concentrate diet.

Observing the fermentation pattern of each strain tolerant to LLOS products of the inoculum from animals fed 50:50\% roughage:concentrate diet, regardless of the concentration of the total flavonoids measured in chrysin, it was observed that the LLOSA2 $(0.001 \mathrm{mg}$ of total flavonoid in chrysin/g of LLOS ) and LLOSC 3 products $(0.030 \mathrm{mg}$ of total flavonoids in chrysin/g of LLOS) selected strains able to ferment all the tested carbohydrate, making necessary the use of markers to measure this parameter with reliability. Cellulose, celobiose, fructose and lactose were fermented by most of the LLOSC 3 tolerant strains, followed by the LLOSA2 tolerant strains. The same sugars were fermented in smaller proportions by LLOSC 1 and LLOSD 1 tolerant strains.

Thus, it was shown that there are different active substances in the evaluated LLOS products. Not necessarily were the highest level of flavonoids and their derivates (mainly contributors of the biological activities of the propolis) in LLOS products proportional to the concentration of the propolis (A, B, C, and D), since there was some interference of the used alcoholic levels $(1,2$, and 3$)$. It is probably that in the highest concentration of propolis and in the highest alcoholic levels that it occurs solubilization of the resins and waxes - contaminants of the propolis that negatively will influence the release of active substances. But also, under low concentration of propolis and alcoholic levels, it may not extract some of the biological compounds that would act upon the ruminal microbiota. Therefore, each type of LLOS can act in distinct population of ruminal bacteria. Hypothetically, the extracts of propolis can present different ways of action on other ruminal population such as the protozoa as observed by Ríspoli et al. (2009), who reported that the product based on propolis LLOSC1 reduced the rumen ciliate protists of buffaloes fed diet 50:50\%.

Differences were observed only for lactose in the fermentation of carbohydrates for the product LLOSC 1 in the two tested diets. The tolerant strains LLOSC1 in the $100 \%$ corn silage diet were more able to ferment lactose ( $96.4 \%$ and credibility interval does not coincide) than in $50: 50$ roughage:concentrate diet $(75.0 \%)$. The bacteria in charge of degrading starch, soluble sugars and the cellulolytic bacteria that comprise the microbiota of a 50:50 diet formed distinct trophic groups and showed different membrane permeability (Gouet \& Jouany 1995; Robson \& Stewart 1997) and they are probably less susceptible to LLOSC1. On the other hand, in the ruminal content of cows fed $100 \%$ roughage, there is the predominance of cellulolytic bacteria and according to Stewart et al. (1997) and Russell (2002), in such conditions, they are more susceptible to additives as for example antibiotics and ionophores.

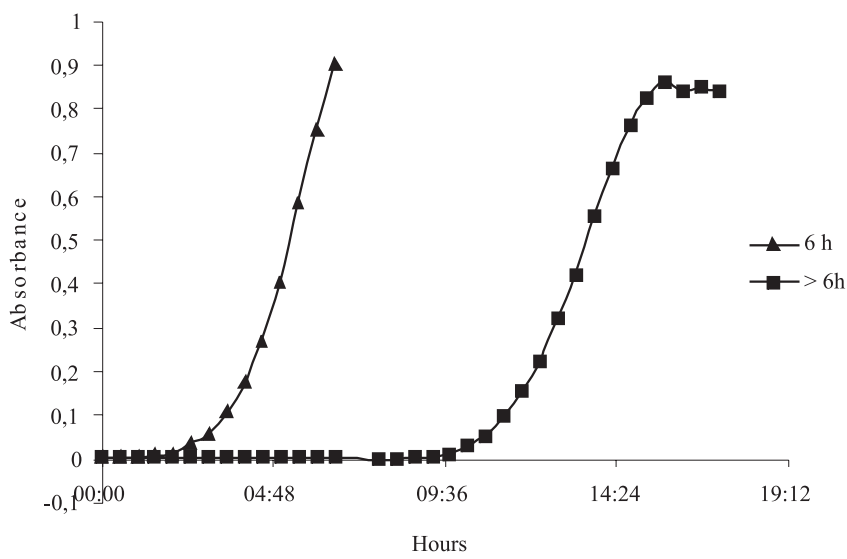

Figure 1 - Example of two types of growth curve of LLOStolerant bacterial strains 
Propolis tolerant strains were divided into two distinct growth patterns (Figure 1): one group of strains growning until 6 hours and 30 minutes of incubation (the time limit of measurement was randomly defined), and other group grew from 8 to 37 hours of incubation. All tolerant strains LLOSA2 grew until 6 hours and 30 minutes of incubation.

Propolis tolerant strains that presented higher lag time (Figure 1), that is, latency state superior to 17 hours, overall, presented higher affinity and ability to degrade cellulose, cellobiose, arabinose, and xylose than soluble sugars, except glucose, and presented mostly the rod shape. Propolis tolerant strains, whose growth was stabilized until 6 hours and 30 minutes of incubation mostly, had the coccobacillus shape. These data corroborate with the literature, since the bacteria Fibrobacter succinogenes that degrades preferably cellulose and cellobiose presents morphology of a rod (Gouet \& Jouany, 1995; Hungate, 1966). Moreover, generally, the fribrolytic bacteria present either longer time of colonization or longer time of latency (lag time) for the cellulose tooling up (Hiltner \& Dehority, 1983). On the other hand, the bacteria Succinomonas amylolytica - that degrades the soluble sugars presents the coccobacillus form (Gouet \& Jouany, 1995).

\section{Conclusions}

The experiment suggests that the tolerance to propolis by the Gram-positive strains are higher. Such predominance is probably due to propolis action mechanism that is involved in the bacterial RNA-polymerase inhibition. For further tests in animals fed $100 \%$ roughage, both products based in tested propolis will be suitable, and for additional experiment with confined animals fed diets with similar proportions of roughage:concentrate, only two additives based in propolis, LLOSC 3 and LLOSA2, are the most suitable ones, since they are tolerated by populations of high metabolic diversity as observed through the growth under different sugars.

\section{Acknowledgments}

To CNPq for the grant of the scholarship during my doctorate course. To EMBRAPA- Gado de leite by the support structure. To trainees Juliana Alves Resende and Thais Barros Ríspoli for help in laboratory tests and to Professor Carlos A. Lopes de Oliveira for assistance in statistical analysis.

\section{References}

ANTUNES, R.M.P.; CATAO, R.M.R.; CEVALLOS, B.S.O Antimicrobial activity of propolis. Revista Brasileira de Farmácia, v.77, p.15-18, 1996.

BROUDISCOU, L.P.; PAPON, Y.; BROUDISCOU, A.F. Effects of dry plant extracts on fermentation and methanogenesis in continuous culture of rumen microbes. Animal Feed Science and Technology, v.87, n.3-4, p.263-277, 2000.

BRYANT, M.P.; BURKEY, L.A. Cultural methods and some characteristics of some of the more numerous groups of bacteria in bovine rumen. Journal of Dairy Science, v.36, p.205, 1953.

COWLES, M.K.; BEST, N.; VINES, K et al. Convergence diagnostics and output analysis. MRC Biostatistics Unit. UK. Version. 0,40, 1995.

FOSTER, J.W. Morphogenesis in bacteria: some aspects do spore formation. The Quarterly Review of Biology, v.31, n.2, p. $102-118,1956$

FRANCO, S.L.; BUENO, J.H.F. Otimização de processo extrativo de própolis. Infarma, v.11, n.11/12, p.48-51, 1999.

GOUET, F.E.; JOUANY, S.P. L'écosistème microbien deu réticulorumen. In: Nutrition des ruminants domestiques. Paris: INRA editions, 1995. p.299-348.

HILTNER, P.; DEHORITY, B.A. Effect of soluble carbohydrates on digestion of cellulose by pure cultures of rumen bacteria. Applied and Environmental Microbiology, v.46, p.642-648, 1983

HUNGATE, R.E. The rumen and its microbes. New York: Academic Press, 1966. p.533.

HUNGATE, R. E. A roll-tube method for cultivation of strict anaerobes. In: NORRISS, J.R.; RIBBONS, D.W. (Eds.) Methods of microbiology. V.3B. New York: Academic Press, 1969. p.117.

LUNN, D.J. (WinBUGS)-A Bayesian modelling framework: concepts, structure, and extensibility. Stat Comput v.10, p.325-37, 2000. Disponível em: <http://mathstat.helsinki.fi/openbugs/>. Acesso em: 28/8/2009.

ODENYO, A. A.; OSUJI, P. O. Tannin-tolerant ruminal bacteria from east African ruminants. Canadian Journal of Microbiology, v.44, n.9, p.905-909, 1998.

PRADO, O.P.P. Produto à base de própolis na nutrição de ruminantes (LLOS). 2005. 78f. Dissertação (Mestrado em Produção Animal) - Universidade Estadual de Maringá, Maringá

R Development Core Team [2009]. R: A language and environment for statistical computing. Vienna: R Foundation for Statistical Computing. Disponível em: <http://www.R-project.org.> Acesso em: 28/8/2009

RÍSPOLI, T.B.; RODRIGUES, I.L.; MARTINS NETO, R.G. et al. Protozoários ciliados do rúmen de bovinos e bubalinos alimentados com dietas suplementadas com monensina ou própolis. Pesquisa Agropecuária Brasileira, v.44, n.1, p.92-97, 2009.

ROBSON, P.N.; STEWART, C.S. The rumen microbial ecosystem 2.ed. London, 1997. p.523-632.

RUSSELL, J.B. Rumen microbiology and its role in ruminant nutrition. Ithaca: James B. Russell, 2002. 119p.

STEWART, C.S.; FLINT, H.J.; BRYANT, M.P. The rumen bacteria In: _- The rumen microbial ecosystem. 2.ed. London: Blackie Academic \& Professional, 1997. p.10-72.

STRADIOTTI JR., D.; QUEIROZ, A.C.; LANA, R.P. et al. Ação do extrato de própolis sobre a fermentação in vitro de diferentes alimentos pela técnica de produção de gases. Revista Brasileira de Zootecnia, v.33, n.4, p.1093-1099, 2004.

TAKAISI-KIKUNI N. B.; SCHILCHER, H. Electron microscopic and microcalorimetric investigations of the possible mechanism of the antibacterial action of a defined propolis provenance. Planta Medicine, v.60, n.2, p.222-227, 1994 